\title{
SISTEM INFORMASI VISUAL PENENTUAN WAKTU PENYINARAN HARIAN KANKER UNTUK TEKNIK S.A.D.
}

\author{
Putu Wida Gunawan ${ }^{1}$, A. A. Ngurah Gunawan ${ }^{2}$, \\ Ni Nyoman Ratini ${ }^{2}$. \\ Prodi Teknik Informatika, Fakultas IKST, Universitas Dhyana Pura, Badung - Bali ${ }^{1}$ \\ Sistem Komputer, STMIK - STIKOM, Denpasar - Bali ${ }^{2}$
}

\begin{abstract}
Visual computer information systems to calculate the daily exposure time for cancer source to axis distance technique has been invented. Patient data can be stored in the system so that the calculation process can be simplified and accelerated. The results obtained are also approaching the calculation of results were conducted manually in Sanglah Hospital Sub-Division Radiotherapy with a difference of 0.033 to 0.334 seconds for engineering SAD, and 0.01 to 0.61 seconds for the SSD technique
\end{abstract}

Keywords : Time daily irradiation of cancer, SAD, SS.D

\begin{abstract}
ABSTRAK
Sistem informasi komputer visual untuk menghitung waktu penyinaran harian kanker dengan teknik source to axis distance telah diciptakan. Data pasien dapat disimpan dalam sistem ini sehingga proses perhitungan dapat dipermudah dan dipercepat. Hasil perhitungan yang didapat juga mendekati dari

hasil manual yang dilakukan di Rumah Sakit Sanglah Sub Divisi Radioterapi dengan selisih 0,033 hingga 0,334 detik untuk teknik S.A.D., dan 0,01 hingga 0,61 detik untuk teknik S.S.D.
\end{abstract}

Kata kunci : Waktu penyinaran harian kanker, S.A.D., S.S.D.

\section{PENDAHULUAN}

Teknologi berkembang pesat seiring dengan perkembangan jaman. Teknologi informasi juga mengalamiperkembangan.

Bahasa pemrograman adalah salah satu contoh dimana program dapat dijalankan dari desktop dan dapat diakses di dunia maya (internet).

Dalam dunia radio terapi, terdapat dua teknik penyinaran radio terapi yaitu, Source to Surface Distance (S.S.D.) dan Source to Axis Distance (S.A.D.) yang memerlukan masukan data beruba waktu (detik). Proses ini memerlukan ketelitian dan kehatihatian yang tinggi, agar efek penyinaran terhadap kanker dapat maksimal dan meminimalkan efek negatif terhadap sel - sel sehat [1].

Nilai waktu di atas, diperoleh dari kalkulasi fisis terhadap data simulasi yang panjang dan kompleks, dimulai dari data simulasi, pendekatan interpolasi sehingga menghasilkan besaran-besaran seperti Tissue Air Ratio, Output Factor, yang kemudian di- hitung lagi sampai memperoleh hasil (waktu) yang dimaksud [2].

Di RS. Sanglah Denpasar, perhitungan penentuan waktu penyinaran harian kanker dilakukan secara manual, dan pengarsipan data pasien dilakukan secara konvensional. Proses perhitungan dimulai dari pencarian data pasien kemudian memasukkan data simulasi sampai menghasilkan data masukan untuk teknik penyinaran, memerlukan waktu yang relatif lama.

Sehingga diperlukan sebuah sistem yang dapat menentukan waktu penyinaran harian kanker dengan teknik S.A.D. dan S.S.D., seta dapat menyimpan data/berkas pasien pada database sehingga dapat diakses lebih cepat. 


\section{TINJAUAN PUSTAKA}

\section{A. Teknik Penyinaran}

1) Source to Surface Distance (S.S.D.) : Teknik penyinaran ini menggunakan Percentage of Depth Dose dimana kedudukan sumber terhadap kulit pasien dipertahankan selalu tetap. Untuk Itu kedudukan pasien yang harus digeser [2].

2) Source to Axis Distance (S.A.D.): Teknik ini menggunakan Tissue-Air Ratio dimana kedudukan sumber terhadap target, dalam hal ini adalah tumor atau kanker, yang diper- tahankan tetap. Teknik ini tidak bergantung pada kedalaman target seperti halnya pada teknik S.S.D[2]. Hubungan antara teknik S.A.D. dan S.S.D. memenuhi persamaan berikut:

S.A.D. = S.S.D. + depth

B. Nilai Sinar (paparan)

Bila suatu jaringan mendapatkan penyinaran dari luat oleh fluks energi tertentu, maka dosis serap yang diterimanya bergantung pada arus dan energi radiasi yang menyinari pada kedalaman titik yang ditentukan penerimanaan dosisnya, dan pada atom jaringan titik itu[1]. Nilai sinar dengan nama khusus Roentgen $(\mathrm{R})$ u $8,77 \times$ $10^{-3} \mathrm{~J} / \mathrm{kg}$.

C. Dosis serap dan Laju dosis serap

Secara matematis dosis serap dirumuskan dengan : $\mathrm{D}=\frac{\mathrm{dE}}{\mathrm{dm}}$ dimana $\mathrm{dE}$ adalah energi yang diserap oleh medium bermassa dm[1]. Laju dosis serap dirumuskan dengan :

$$
\mathrm{D}=\frac{\mathrm{dD}}{\mathrm{dt}} .
$$

\section{Pesawat Telecobalt-60}

$\mathrm{Ra}^{226}, \mathrm{Cs}^{137}, \mathrm{Co}^{60}$ adalah beberapa jenis radionuklida yang digunakan untuk teleterapi. Dari seluruh radionuklida, $\mathrm{Co}^{60}$ telah terbukti paling layak digunakan untuk penyinaran eksternal radioterapi. Hal ini disebabkan $\mathrm{Co}^{60}$ memiliki ke- mungkinan aktifitas lebih tinggi (curie per gram), radiasi keluaran yang lebih besar dan energi foton yang lebih tinggi dibandingkan radionukida lainnya. sebagai tambahan juga $\mathrm{Ra}^{226}$ memiliki self-absorption yang lebih besar dibandingkan $\mathrm{Cs}^{137}$ dan $\mathrm{Co}^{60}[1]$.

E. Informasi dan Database

Data sebagai bahan baku informasi didefinisikan sebagai sekelompok simbolsimbol yang teratur mewakili kuantitas, tindakan, benda dan lain sebagainya [3].

Data selanjutnya diolah dalam bentuk struktur data sehingga menghasilkan suatu yang berguna pada saat dibutuhkan. Database merupakan sistem penyimpanan data terkomputerisasi. Perangkat lunak yang digunakan untuk pengolahan database disebut DBMS (Database Management System ) yang menggunakan bahasa baku yaitu SQL (Structure Query Language).

SQL selanjutnya dibagi menjadi dua yaitu: Data Def- inition Language, yang digunakan dalam pembuatan database dan table baru. dan Data Manipulating Language, yang digu- nakan untuk memanipulasi data pada database [3].

F. Web Programming

Website pada awalnya berisi halamanhalaman yang ter- hubung dan bersifat statis, sehingga pengguna adalah pengguna pasif. Ketika akhirnya ditemukan tag <FORM>, barulah pengguna bisa aktif berinteraksi dengan halaman website. Dan mulailah era web yang dinamis.

1) Personal Home Page Tools: PHP awalnya merupakan singkatan dari Personal Home Page, yang akhirnya dike- nal sebagai PHP: Hypertext Preprocessor [4]. Kode PHP dapat disisipkan pada kode HTML. Kode PHP disisipkan didalam tag PHP yaitu: <?php ..kode php.. ?>. PHP mendukung berbagai macam tipe data, seperti: integer, double, floating point, string. Dalam pendeklarasian variabel, cukup dengan menambahkan simbol \$ pada nama variable [5]. Se- bagai contoh \$namavariabel.

PHP juga mendukung berbagai operator seperti aritmatika, penugasan, perbandingan, binary, logika, serta tertiary. Dalameksekusinya terdapat prioritas operator [3].

2) Apache: Apache adalah salah satu mesin penterjemah

yang dapat menterjemahkan kode php dengan sangat baik. Apache juga berjalan di lintas platform dan dapat di download dengan gratis dari internet [3]. 
3) MySQL: MySQL adalah salah satu DBMS yang terkenal. Hal ini disebabkan oleh hasil yang diberikan adalah optimal secara kecepatan dan manajemen data. MySQL juga bersifat open-source yang membuat MySQL digunakan oleh banyak pengguna tanpa membuang dana. MySQL juga ber- jalan di lintas platform dan dapat di download secara gratis di internet [3].

G. Perhitungan Waktu Penyinaran Harian

- Laju Dosis Serap : $\dot{D}_{t}=\dot{D}_{0} \exp ^{\frac{0,693 \times t}{T_{\frac{1}{2}}}}$

- Sisi Lapangan Ekivalen: $\frac{4 \times \text { luas lapangan penyinaran }}{\text { Kelilinglapangan penyinaran }}$

- Tissue Air Ratio

- T.A.R. $=\frac{\text { Dosis serap pada kedalaman tertentu }}{\text { dosis serap pada phantom diudara }}$

- Percentage Depth Dose

- P.D.D. $=\frac{\text { Dosis serapdititik } p}{\text { dosis serap pada kedalaman acuan }} \times 100 \%$

- Output Factor

- $O F\left((S A D) ; B^{2}\right)$

$O F\left(80 ;\left(B \times \frac{80}{(S A D-d)}\right)^{2}\right) \times \frac{(80)^{2}}{(S A D-d)^{2}}$

- Waktu Penyinaran harian :

- $T=\frac{\dot{D}}{T \cdot A \cdot R \times O \cdot F \cdot \times T \cdot F \cdot \times W \cdot F \cdot \times \dot{D_{t}}}$

\section{TINJAUAN PUSTAKA}

A. Tempat dan Waktu Penelitian

Tempat penelitian dilaksanakan di Lab. Komputasi Jurusan Fisika FMIPA Univ. Udayana. Waktu pelaksanaan bulan Juli 2006 hingga Juni 2007.

B. Alat yang digunakan

Dalam penelitian ini digunakan alat-alat sebagai berikut:

- 1 unit PC Pentium 3, Memory $256 \mathrm{MB}$, dilengkapi dengan PHP, Apache, Mysql.

- Tabel Spesifik T.A.R.

- Tabel Spesifik P.D.D.

- Tabel Spesifik O.F.

- Data Simulasi pasien.

C. Spesifikasi Program

Adapun spesifikasi program adalah:

1) Program dapat memasukkan data pasien dalam bentuk basis data.
2) Program dapat memanipulasi data pasien.

3) Program dapat menghitung waktu penyinaran harian kanker pasien.

\section{HASIL DAN PEMBAHASAN}

Ada empat jenis perhitungan yang dilakukan, yaitu perhitungan manual dengan teknik S.S.D. dan S.A.D. serta perhitungan dengan menggunakan program dengan teknik S.S.D. dan S.A.D.

Table II

HASIL PERHITUNGan S.S.D.

\begin{tabular}{|c|c|c|c|c|}
\hline Identitas & \multicolumn{2}{|c|}{ M.K. } & \multicolumn{2}{|c|}{ K.M. } \\
\hline Data Masukan & & & & \\
\hline Tgl. Simulasi & \multicolumn{2}{|c|}{$20-07-2004$} & \multicolumn{2}{|c|}{$30-06-2004$} \\
\hline Lap. Penyinaran $(\mathrm{cm})$ & \multicolumn{2}{|c|}{$6 \times 13$} & \multicolumn{2}{|c|}{$7 \times 7$} \\
\hline T.F & \multicolumn{2}{|c|}{0.94185} & \multicolumn{2}{|c|}{0.94185} \\
\hline W.F. & \multicolumn{2}{|c|}{1} & \multicolumn{2}{|c|}{1} \\
\hline Kedalaman $(\mathrm{cm})$ & \multicolumn{2}{|c|}{4} & \multicolumn{2}{|c|}{6} \\
\hline FDH (cGy) & \multicolumn{2}{|c|}{200} & \multicolumn{2}{|c|}{200} \\
\hline Hasil Perhitungan & Manual & Komputer & Manual & Komputer \\
\hline Laju Dosis Serap & 218.22 & 218.22 & 219.80 & 219.80 \\
\hline Lap. Ekivalen $\left(\mathrm{cm}^{2}\right)$ & 6 & 6.13 & 6 & 6.08 \\
\hline Nilai P.D.D. & 81.36 & 81.3575 & 70.19 & 70.236 \\
\hline Nilai O.F. & 0.957 & 0.958 & 0.957 & 0.578 \\
\hline Waktu Penyinaran (s) & 75 & 74.84 & 86 & 86.1467 \\
\hline
\end{tabular}

\section{KESIMPULAN DAN SARAN}

Dari hasil penelitian dapat diambil kesimpulan sebagai berikut:

1) Sistem informasi visual ini dapat mempercepat perhitungan waktu penyinaran harian kanker.

2) Sistem dapat menyimpan data pasien pada database dan juga dapat memanipulasi data tersebut.

3) Selisih nilai yang diperoleh antara perhitungan manual dengan komputer adalah antara 0.033 s.d. 0.334 untuk teknik S.A.D. dan 0.01 s.s. 0.61 untuk teknik S.S.D.

Dan hasil penelitian dapat dikembangkan lagi dengan saran sebagai berikut:

- Untuk keamanan perlu digunakan sistem keamanan terbaru. 


\section{DAFTAR PUSTAKA}

[1] B. Blacburn and S. Shahabi, Blackburn's Introduction to Clinical RadiationTherapy Physics. Medison Corporation Publishing, 1989.

[2] I. G. S. Dharmawan, "Visualisasi penentuan waktu penyinaran harian kanker untuk teknik s.s.d.," 2006.

[3] A. Kadir, Dasar Pemrograman Web Dinamis menggunakan PHP. ANDI Yogyakarta, 2003.

[4] A. Harris, PHP/MySQL Programming for the Absolute Beginner. Premier

Press, 2003.

[5] I. Irawan, "Php? siapa takut!," 2006. 